\title{
WASTE STRATEGIES FOR MANAGING EXCESSIVE SLUDGE IN WATER RESOURCES
}

\author{
MARCELO M. VEIGA ${ }^{1,2} \&$ DALTON M. SILVA ${ }^{1}$ \\ ${ }^{1}$ Environmental Health Department, National School of Public Health, Oswaldo Cruz Foundation, \\ Ministry of Health, Brazil. \\ ${ }^{2}$ Strategic Management Department, Business School, Federal University of Rio de Janeiro State, \\ Ministry of Education, Brazil.
}

\begin{abstract}
Brazil has been planning to universalize water-related services for a long time. Due to budget constraints, only $40 \%$ of overall domestic sewage receive proper treatment before final discharge. Even though, direct sewage discharges represent major threats to Water Resource Managers, it creates challenge to Waste Managers. This study analyzed waste strategies for managing excessive lake sludge. In the selected water resource, raw sewage was discharged directly for a lengthy period. Massive portion of biosolids have accumulated on the bottom of the lake, resulting in considerable sludge layer. A preliminary sludge dredging attempt resulted in algae bloom, steady pollution, eutrophication, and fish death. However, the main expected hazard is the amount of solid waste generated during the sludge removal process. The preferred waste strategy by local officials was disposing the sludge in an open dumping area. Other potential sludge management strategies were: composting; geotextile bags; brick industry (recycling); incinerating; open-dump and landfilling. The results of sludge characteristics indicated no hazardous compounds and a sizable percentage of inorganic matter (85\%). Open dump disposal was assumed to be illegal. The landfill solution did not enable any energy or material recovery and should be considered only as the least preferred solution. The geotextile and incineration alternatives indicated to be costly. Composting was considered ineffective due to high inorganic ratio and logistic costs. The low logistics costs and the sludge characteristics makes brick manufacturing comparatively efficient. Therefore, this study proposed as the optimal waste strategy, recycling the sludge as raw material in the local brick manufacturing facility. However, due to severe public budget constraints, the implementation of any sludge management strategy (dredging and disposal) is still contingent on availability of financial resources.
\end{abstract}

Keywords: Brick, Sludge, Waste Management, Water Resource.

\section{INTRODUCTION}

The World Health Organization (WHO) highlights the close relationship between human health and water quality. The lack of adequate drinking water supply and sewage infrastructures affects the health of the population and the entire ecosystem. A sizable percentage of diseases affecting developing countries could be directly related to poor sanitation systems. A proper sanitary system has a strong impact on reducing water-related diseases and infant mortality. A poor sanitation infrastructure should be a major concern for public officials [1].

Brazil is a continental-size country with 8.5 million square kilometers divided in 5.570 municipalities accommodating 208 million people. Currently, only $40 \%$ of domestic sewage are properly treated before final discharge in the water bodies. A large part (18\%) of the Brazilian population does not have access to treated water. Over half of the population does not have access to sewage collection; from the total collected sewage, $1 / 3$ is not treated [2].

Brazil has $12 \%$ of the world's available water resources (around 177,900 $\mathrm{m}^{3} / \mathrm{s}$ ), which corresponds to 53\% of all water resources in South America [3]. The perception of water supply abundance have built up population and public officials culture for extravagance, postponing necessary investments for an efficient use and protection of water resources [3]. Therefore, Brazilian water management policy derives from a combination of bad priority, uncontrolled 
population growth, unplanned urban scenario, industrialization, and agricultural expansion, which turned water systems into vulnerable bionetworks $[3,4]$.

In 2007, the National Sanitation Directive (Law 11,445/07) established a regulatory framework for water and sanitation [5]. This rule was innovative by introducing the basis for public policies and regulations, trying to encourage private investments in infrastructure.

The Resolution 357/2005 enacted by the Brazilian National Environmental Council (CONAMA) established guidelines for classifying water bodies according to their uses, aiming to establish mandatory water quality standards, including 13 water tiers. Each tier was defined according to the water quality required for complying with each designated use [6].

This rule also defines physical and biochemical water quality standards (WQS) for a list of contaminants and substances, e.g. Biochemical Oxygen Demand (BOD), Dissolved Oxygen (DO), floating materials, oils and greases and solid objectionable waste. BOD is a parameter for measuring the potential pollution of certain biodegradable substances in relation to dissolved oxygen consumption. DO values are essential to assess the natural conditions of water and to assess environmental impacts (e.g. eutrophication and pollution) caused by organic matter discharge $[6,7]$.

CONAMA enacted Resolution 430/11, which altered Resolution 357/05 in respect of sewage discharges in water bodies. This rule established stricter conditions, standards and guidelines for managing effluent (domestic and industrial) discharges on water bodies. According to the new rule, the effluent from any source may only be discharged directly or indirectly into a water body after being properly treated [8].

Other relevant legislations are: Drinking Water Rule (Administrative Rule 2.914/2011) enacted by the Ministry of Health, stating standards for drinking water [9]; and CONAMA Resolution 274/2000, which states standards for any water resources (river, lake, lagoon, ocean, and sea) that have the possibility to be in touch with human beings or animals [10].

Brazil has neglected water-related services for a long time. In most municipalities, raw sewage is directly released into water bodies. The Brazilian Water Agency (ANA) [11] concluded that the discharge of raw sewage in water resources is the main cause of our environmental degradation. Despite of the existence of strict water legislation, poor enforcement resulted in low regulatory compliance.

On average, $83 \%$ of total pollution are covered by public drinking water systems $(93 \%$ in urban Areas). Large portion of domestic sewages still does not receive proper treatment before final discharge. 50\% of domestic sewage are collected (58\% in urban areas), and from this amount $74 \%$ are treated. This numbers indicated that only $42 \%$ of the overall domestic sewage are collected and treated before final release, which poses a major challenge to those responsible for water policies [12].

When raw sewage is directly released to small water resources, they lean towards saturation very quickly, due to bacterial and algal reproduction during the decomposition process of organic matter. Depending on the amount of raw sewage released, the size of the water body, and the environmental vulnerability, some water resources has been continuously operating biologically as a stabilization pond [13]. This biological degradation process of organic matter is relatively slow; an excessive amount of nutrients can produce a large amount of sludge containing microorganisms, see Fig. 1.

In polluted water systems, biological processes naturally reduce organic matter and nutrients. A stabilization pond is a natural biological treatment of polluted waters, where living organisms (bacteria and algae) use organic matter as nutrients. Over the time, a great part of the organic matter is consumed by these living organisms, biodegrading, and mineralizing. Some of these materials deposit at the bottom of the water body resulting in a layer of sludge. 


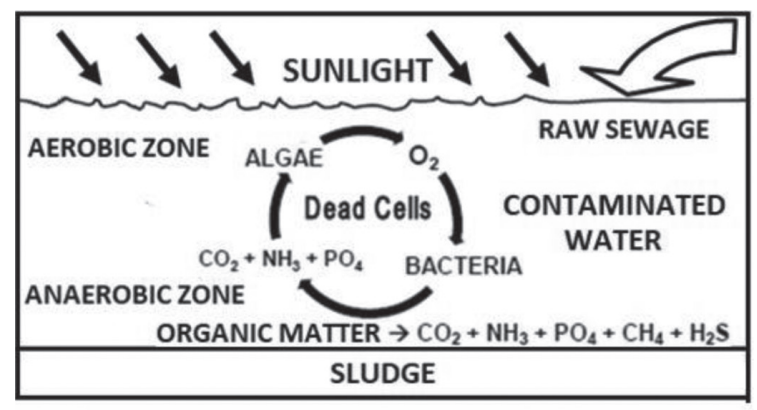

Figure 1: Biological process scheme

Over the years, the amount of sludge accumulated can be an environmental risk and become a waste management hurdle, especially for small municipalities.

There is not much data on organic matter percentage in sludge removed from artificial lakes. To establish a viable parameter, this study utilized the existing technical data for monitoring the sludge from wastewater plants and stabilization ponds.

The objective of this study was to analyze waste management alternatives for dealing with the removal of the sludge accumulated in a polluted lake located in a small municipality. The waste management strategies considered in this analysis were: composting; disposal in geobags; disposing in open dumps; incineration; use in brick production; and landfilling. In a comparative analysis, this study tried to internalize all social, economic and environmental costs of treating and disposing of the sludge associated with each alternative.

The sludge usage in agriculture is regulated by the Resolution 375/06 [14], which recommends a maximum of $70 \%$ of volatile solids. This recommendation is related to the need for sludge stabilization, which increases as the proportion of TVS decreases.

As a case study, this study selected an artificial lake in a small Brazilian municipality (30,000 people), which has been polluted by a large amount of raw domestic sewage, generating a huge layer of sludge deposited on the bottom.

\section{SELECTED WATER RESOURCE}

A mild climate and pleasant landscape municipality is a popular traveler destination. Over the last decades, large amount of raw domestic sewage has been discharged directly into an artificial lake of this municipality (30,000 people) at the inland mountain region of the Rio de Janeiro State, which has an urbanization rate of $84 \%$ and only $25 \%$ of residences with drinking water supplied by public systems; while $74 \%$ obtain their water directly from wells or springs. The municipal sewer collection system only serves $13.5 \%$ of the homes, while $65.3 \%$ have proper septic tanks, $10.7 \%$ use rudimentary septic pits, $7.5 \%$ are connected to uncovered ditches and $2.5 \%$ discharge their sewage directly into a water body. Historically, no collected sewage received treatment before discharge into water bodies [2, 15].

This polluted water resource is the main natural attraction of this pleasant touristic region. It has a shoreline of slightly over $2 \mathrm{~km}$, a water surface area of $80,000 \mathrm{~m}^{2}$, and a watershed that covers $3.8 \mathrm{~km}^{2}$. Besides its relevance for recreational activities, it is important for its scenic beauty, drainage and ecological role on the region. The lake's bathymetry assessment indicated that water depth varied from 3 to 4 meters in the middle region of the lake; and from 0 to 1 meters in regions closer to the lakeshore. 
Previous studies $[13,16]$ demonstrated that this lake has been progressively polluted, mainly by organic matter from domestic sewage discharge. In these studies, several physicalchemical and microbiological analyses were performed corroborating that the lake was polluted mainly by organic matter, indicated by Biological Oxygen Demand (BOD) and fecal coliforms over legal standards. The laboratory results indicated that the water quality in this lake were typical to those values find in stabilization ponds.

The living organisms (e.g. bacteria and algae) present in the natural biological process (Fig. 1) consume most of the organic matter and nutrients. However, part of the materials has deposited on the bottom of the lake generating a large layer of sludge. Over the years, large sludge accumulation in a small water body became an environmental risk.

As a preliminary estimate, this study measured the amount of sludge and the water layers from 30 selected sampling spots along the lake. This sampling spots were selected to cover the whole area of the lake. Each sampling result was repeated at least three times for minimizing measuring errors. These measures were taken from a small floating boat with simple measurements instruments, such as: calibrated stick and rope with weight. These results are indicated on Table 1.

Table 1 showed sludge layer varying from 1 to 2 meters and water layer from 1.5 to 4 meters. As expected, the higher layer of sludge was found in the middle of the lake, reaching a maximum of 1.9 meter. These results indicated an average layer of sludge around 1.5 meters sitting on the bottom of this artificial lake. The estimate is that the lake has a total sludge volume of $120,000 \mathrm{~m}^{3}$ (area of $80,000 \mathrm{~m}^{2}$ times an average sludge layer of 1.5 meters).

Recently, local officials have implemented a clean-up project to reduce pollution in the lake, including a wastewater treatment plant and a sewage collection system. However, it will take a long time before the water quality in the lake reaches legal standards naturally. To clean up the lake, it is mandatory to remove a great part of the deposited sludge. A conservative estimate is that the deposited sludge has reduced the volume of water in the lake by at least $50 \%$, making the natural biological cleaning process even slower, see Fig. 1.

Table 1. Results of sludge and water layers from 30 sampling spots (in meters)

\begin{tabular}{lllllllllll}
\hline Spot & $\mathbf{1 .}$ & $\mathbf{2 .}$ & $\mathbf{3 .}$ & $\mathbf{4 .}$ & $\mathbf{5 .}$ & $\mathbf{6 .}$ & $\mathbf{7 .}$ & $\mathbf{8 .}$ & $\mathbf{9 .}$ & $\mathbf{1 0 .}$ \\
\hline Sludge & 1.8 & 1.5 & 1.4 & 1.1 & 1.2 & 1.1 & 1 & 1.9 & 1.9 & 1.7 \\
Water & 1.5 & 1.2 & 2.8 & 3.2 & 3.7 & 3.7 & 3.6 & 2.3 & 1.9 & 1.5 \\
Total & 3.3 & 2.7 & 4.2 & 4.3 & 4.9 & 4.8 & 4.6 & 4.2 & 3.8 & 3.2 \\
\hline Spot & $\mathbf{1 1 .}$ & $\mathbf{1 2 .}$ & $\mathbf{1 3 .}$ & $\mathbf{1 4 .}$ & $\mathbf{1 5 .}$ & $\mathbf{1 6 .}$ & $\mathbf{1 7 .}$ & $\mathbf{1 8 .}$ & $\mathbf{1 9 .}$ & $\mathbf{2 0}$ \\
\hline Sludge & 1.3 & 0.9 & 1.5 & 1.6 & 0.7 & 1.4 & 1.4 & 0.7 & 1.5 & 1.3 \\
Water & 2.5 & 2.5 & 2.8 & 3.0 & 3.0 & 3.0 & 3.0 & 2.8 & 2.8 & 3.3 \\
Total & 3.8 & 3.4 & 4.3 & 4.6 & 3.7 & 4.4 & 4.4 & 3.5 & 4.3 & 4.6 \\
\hline Spot & $\mathbf{2 1 .}$ & $\mathbf{2 2 .}$ & $\mathbf{2 3 .}$ & $\mathbf{2 4 .}$ & $\mathbf{2 5 .}$ & $\mathbf{2 6 .}$ & $\mathbf{2 7 .}$ & $\mathbf{2 8 .}$ & $\mathbf{2 9 .}$ & $\mathbf{3 0 .}$ \\
\hline Sludge & 1.4 & 0.2 & 1.2 & 1.5 & 1.0 & 0.8 & 1.9 & 0.9 & 1.1 & 0 \\
Water & 2.3 & 2.3 & 2.7 & 3.0 & 2.0 & 3.0 & 2.3 & 2.3 & 2.4 & 1.5 \\
Total & 3.7 & 2.5 & 3.9 & 4.5 & 3.0 & 3.8 & 4.2 & 3.2 & 3.5 & 1.5 \\
\hline
\end{tabular}


Therefore, any clean-up project must include a sludge removal phase. A preliminary sludge dredging was attempted, which resulted in bad publicity and population panic, due to algae bloom, steady pollution, eutrophication, and fish death. This failed attempt raised a red flag on sludge removal, demanding further studies for the optimal strategy [13].

On the other hand, the small amount of sludge removed during just the preliminary dredging attempt was an advice of the environmental risks associated with the cleanup process. The best sludge management strategy represents a public challenge for this small municipality. The waste management alternatives for disposing and treating a huge amount of sludge to be removed depends heavily on its characteristics and budget availability.

\section{SLUDGE CHARACTERISTICS}

This study assessed sludge characteristics (amount, metal contamination, and organic matter percentage). Preliminary, this study analyzed the concentration of volatile suspended solids (organic matter) and metals (lead, cadmium, and zinc) in ten sampling spots, see Table 2.

The ten sampling spots were selected within 10 to $15 \mathrm{~m}$ distance range of the lake shore, except for point 7 , which was in the middle of a bridge crossing the lake. The spot selection tried to reduce the likelihood of contaminant dilution, reproducing possible worst-case scenarios. The sampling procedures were also restricted by budget constraints and operational limitations. Even though, the sewage collection system was already in place, during the sampling procedures, it could be noticed the presence of untreated sewage still been discharged directly into the lake.

In technical literature [17] digested secondary sludge have TVS percentage between $60 \%$ and $80 \%$, while digested primary sludge would have TVS percentage between $30 \%$ and $60 \%$.

The results in Table 2 were lower than typical values of TVS percentage obtained from sludge of wastewater plants in Brazil. A similar study of sludge generated from two wastewater plants in Brazil [18] indicated an average value of total volatile solids of $35 \%$.

In order, to corroborate these results, this study also analyzed three sludge samples from a sewage treatment plant. The results of these analysis indicated an average TVS percentage of $36 \%$, which is similar to the results indicated in the literature.

A tentative explanation for the low TVS results indicated on Table 2, compared to commonly expected from wastewater plants, could rely on the age of the sludge and the biological decomposition process (mineralization). This artificial lake was originally built, over 150 years ago, as a water dam for agriculture. There is no information on any sludge removal or cleaning process in this lake during the last century. Even though, the raw sewage discharge into the lake has been occurring continuously over decades, the average sludge age remains very high. Probably, the biological process of mineralization had occurred. In this sludge, the organic nutrients (organic matter) were majorly decomposed of into inorganic substances, explaining the low TVS values presented in Table 2 .

This study also performed analysis searching for hazardous metals (lead, zinc and cadmium) on four sludge samples. This study selected the four samples, which indicated the

Table 2: Total Volatile Solids (organic matter) and Total Fixed Solids (TFS).

\begin{tabular}{llllllllllll}
\hline Spots & $\mathbf{1}$ & $\mathbf{2}$ & $\mathbf{3}$ & $\mathbf{4}$ & $\mathbf{5}$ & $\mathbf{6}$ & $\mathbf{7}$ & $\mathbf{8}$ & $\mathbf{9}$ & $\mathbf{1 0}$ & Mean \\
\hline TVS (\%) & 13.2 & 13.6 & 15.8 & 16.4 & 17.1 & 15.5 & 14.9 & 13.7 & 12.7 & 7.9 & 14.1 \\
TFS (\%) & 86.8 & 86.4 & 84.1 & 83.6 & 82,9 & 84.5 & 85.1 & 86.3 & 87.3 & 92.1 & 85.9 \\
\hline
\end{tabular}


Table 3: Sludge results of lead, cadmium, and zinc.

\begin{tabular}{lllllll}
\hline Spots & \multicolumn{7}{c}{ Metals* $^{*}$} \\
\hline & $\mathrm{Pb}(\mathrm{mg} / \mathrm{kg})$ & $\mathrm{RSD}(\%)$ & $\mathrm{Zn}(\mathrm{mg} / \mathrm{kg})$ & $\mathrm{RSD}(\%)$ & $\mathrm{Cd}(\mathrm{mg} / \mathrm{kg})$ & $\mathrm{RSD}(\%)$ \\
\hline 1 & 55.79 & 5 & 91.22 & 3 & 7.82 & 5 \\
3 & 69.07 & 7 & 117.77 & 9 & 39.64 & 2 \\
5 & 65.57 & 0.2 & 83.77 & 5 & 8.23 & 7 \\
10 & 52.10 & 5 & 67.93 & 2 & 7.45 & 7 \\
Legal & 300 & & 2,800 & & 39 & \\
Standard & & & & & & \\
\hline
\end{tabular}

*RSD (Relative Standard Deviation) values should be lower than $10 \%$.

higher contamination of organic matter in previous analyses. According to the Resolution $375 / 06$, the analyses of lead, cadmium, and zinc should be conducted according to the USEPA SW-846 Method 3050 Acid Digestion of Sediments, Sludges, and Soils [19]. The results and the allowed concentration of metals in sewage sludge are indicated in Table 3.

There is no potential source for metal contamination on surrounding areas and no industry within a 20 kilometers distance. It was expected that the concentrations of metals in the sludge would be very low, due to the absence of industrial effluents. This assumption was corroborated by the lead, cadmium, and zinc results according to legal standards; indicating that metal contamination should not be a limitation for using lake's sludge for agricultural, industrial or any other use.

In other areas, if there are industries near-by, metal contamination should be determined. Some concentrations of metals, e.g. mercury and nickel could be very dangerous. Mercury contamination is not allowed due to the potential occupational risk associated to its release. The presence of mercury in the sludge jeopardizes any further industrial or agricultural use.

This study collected, at diverse moments, several sludge samples from different spots in the lake. In these samples, the results indicated that the sludge had an average of $75 \%$ humidity and over $85 \%$ of inorganic matter (less than $15 \%$ of organic matter). There was an average of $271 \mathrm{~g}$ of total solids per liter of sludge, representing $229 \mathrm{~g}$ of inorganic matter and $42 \mathrm{~g}$ of organic matter.

These results indicated an aged sludge and a total expected volume of dried sludge to be disposed is $30,000 \mathrm{~m}^{3}\left(25 \%\right.$ of $\left.120,000 \mathrm{~m}^{3}\right)$. The long decomposition process (mineralization) associated with inorganic matter carried by rainwater have influenced the sludge characteristics as mostly inorganic. As noticed, this amount of inorganic matter is not typical when compared to values found in primary and secondary sludge from stabilization ponds and from sewage treatment facilities.

\section{SLUDGE MANAGEMENT ALTERNATIVES}

There are two main expected environmental impacts in managing excessive sludge from a water resource: dredging and disposing. Sludge dredging is a necessary clean-up phase, which should impact the natural ecology. However, the larger expected environmental impact is the waste generated from sludge removal, which requires proper disposal. 
This study analyzed some sludge management alternatives for disposing this excessive removed sludge from the lake: composting; dewatering in geotextile bags; incineration; recycling in brick manufacturing and landfilling.

The primary alternative considered by local officials is the least expensive option, which is disposing the sludge in an open waste dump, which was closed recently. Unfortunately, disposing urban waste in open dumps remains a frequent practice in Brazil. Every day, public authorities allocate more than $40 \%$ of overall municipal waste collected (80,000 tons) in open dumps [20]. This "preferred" option is illegal and did not internalize all costs involved. Thus, this study did not consider this illegal option as a viable alternative, because its high environmental impacts would make initial "savings" ephemeral at best.

Worldwide, landfilling is considered the most cost-effective alternative and is assumed to be the oldest waste management strategy. This competitive advantage makes landfilling the desired alternative for waste managers, especially in large countries like Brazil. Waste strategies require high infrastructure investments and large operational costs. Landfill is basically a disposal place for burying and covering waste, which makes it less costly.

Lately, the selected municipality allocated public funds to build up a small sanitary landfill, located near the old dump place. In 2012, this landfill initiated operation, disposing local domestic solid waste. This landfill was designed with the life expectancy of twenty years. Usually, small landfills have lower economy of scale, which increases operational costs drastically. Over the years, this local landfill displayed many operational difficulties and had never functioned according to legal standards. Environmental inspections led to few temporary shut downs as consequence of improper operation and lack of leachate treatment. Due to poor management, this landfill reached full capacity in just four years (2016) and was permanently closed. Currently, the local urban waste should travel 70 kilometers for final disposal in a large private landfill.

As a waste management strategy, landfill does not recover or reuse material or energy. In many countries there is an ongoing shift away from landfills towards processes involving recycling for using waste to generate energy and as raw material in manufacturing processes. Among many disadvantages, landfills require large areas, which are difficult to convert for future uses; require leachate management to protect nearby water bodies; and need to control gas emission. Landfill should be the final disposal intended for waste that cannot be recycled or reused [21]. Thus, this study assumed that sludge landfilling should be considered only as the less feasible alternative.

Composting is a biological aerobic process of decomposing organic waste. After a period, the aerobic microorganisms break down organic matter into compost at presence of water, oxygen, carbon, and nitrogen. Aerobic microorganisms consume oxygen, producing heat, carbon dioxide and ammonium. The resulting compost can be used by plants in the agriculture. Anaerobic digestion is an alternative form of organic decomposition, which involve different microorganisms and processes.

In Brazil, composted sludge for agriculture should meet legal requirements [16]. Legislation provides limits for the quantity of heavy metals and pathogens. These parameters are applied to each potential future use. Usually, sludge cannot be not used in agriculture due to potential contamination or no rural production within an economical distance [22].

During the decomposition process, elevated temperatures should be avoided to maintain thermophilic organisms. The hot temperatures, which may occur in initial phases of the process, help to eliminate pathogenic organisms in the sludge [14]. To improve composting efficiency, the sludge should be mixed with materials that are structurally rich in carbon to 
obtain efficient composting. Sludge composting reduces waste volume and produce a final product with low potential hazard. However, this study's sludge characteristics indicated low percentage of organic matter making composting an ineffective alternative.

Incineration is a thermal decomposition process via oxidation that reduces the volume and weight of the waste, making it less toxic. It is assumed to be a process associated to high operational costs and that can cause atmospheric pollution in processes releasing dioxins and furans. However, advanced incineration technologies incorporate sophisticated filter systems and energy use, placing waste incineration as environmentally attractive alternative worldwide $[23,24]$.

In typical management hierarchy, waste incineration is preferred to landfill. In energy efficiency, incineration is a dominant solution compared to landfill. Even considering that some waste landfilling is inevitable, an efficient management strategy should be to divert certain types of waste from landfills. At least, alternative waste technologies must be used to reduce the demand for waste disposal, which will increase the useful life of the current landfills, postponing the need for new facilities $[25,26]$.

Unlike most developed countries, where landfills are almost banned, and incineration is considered; Brazilian law virtually banned waste incineration and encouraged landfill. Recycling is still a myth, imposing efficient segregation and vigorous recycling market, which are both inexistent in Brazil. Brazilian public officials assume the feasibility of landfills, the desire of recycling and impracticality of incineration.

In Brazil, because of environmental and financial constraints, there are just a few operational incinerators for hazardous waste. The ashes generated from incineration can be used as raw material in manufacturing processes. Ashes with high concentrations of heavy metals should be buried in especial cells in sanitary or industrial landfills. Incineration is the main technology for waste contaminated with hazardous substances. The elevated operational costs associated to sludge's results indicating no hazardous contaminants, makes incineration an inefficient waste strategy for the present study [27].

Geotextile dewatering tubes (Geotubes) can be used for removing water from sludge (dewatering). Geotubes are built with synthetic permeable resistant membrane, which can cope with large amount of sludge leading to great volume reduction. Geotubes can have large-diameters that can withstand high pressures in the filling stage and whose surface porosity permits drainage of the water contained in the sludge. After sludge dewatering, dried sludge can be directly disposed or used [28, 29].

Geotubes operate in three phases: confinement, when the wet sludge is pumped to the tube; dewatering, when the sludge releases the water, which passes through the membrane; and consolidation, when after the tube is filled with dried sludge (dewatered). Geotubes are widely used to dewater and concentrate sludge. Even tough, Geotube can reduce the sludge volume, it does not solve the main waste management problem: there would be a huge amount of dried sludge that still needs to be disposed. Thus, the final disposal or use of the resulting dried sludge can represent a hassle for a small municipality $[28,29]$.

The huge amount of sludge generated every year in wastewater, water treatment, and lake processes creates a major challenge for waste managers. Generally, these types of material are landfilled. Bricks are an extensively used construction material. Typical firing bricks are produced with clay at elevated temperature, requiring bulky quantity of raw materials and high energy usage leading to large carbon footprint. Environmental restrictions resulted in clay shortage for brick manufacturing in many places. 
As an alternative, several authors have studied the viability of producing bricks by incorporating waste as partial replacement for original raw materials [30-34]. These studies analyzed the effects on brick quality after mixing distinct types of waste with clay as raw material. They analyzed technical, economic, and environmental factors for enabling marketable manufacture of bricks produced with waste. Similar studies [35-40] have analyzed the use of wastewater, water treatment, and lake sludge as brick raw materials.

The results of these studies indicated that sludge mix ratio and firing temperature were crucial to determine bricks final quality. The percentage of organic matter also influence final brick physical characteristics, e.g. compressive strength, weight, porosity, and water adsorption. Generally, up to $30 \%$ of sludge can be mixed with clay, adjusting moisture level to $20 \%$ and monitoring the reduction in compressive strength.

Tay [41] investigated the use of dried sludge in brick manufacturing. The results indicated that $40 \%$ is the maximum percentage of dried sludge that can be mixed with clay for brick making. The typical compressive strength of the bricks is $87.2 \mathrm{~N} / \mathrm{mm}^{2}$ for $0 \%$ of sludge, decreasing to $37.9 \mathrm{~N} / \mathrm{mm}^{2}$ for $40 \%$ of dried sludge.

Eliche-Quesada et al. [42] analyzed the influence of diverse types of waste addition on the linear shrinkage, bulk density, water absorption, and mechanical and thermal properties in brick manufacturing. The results of waste addition indicated that water absorption increased over 35\%; compressive strength decreased by $19 \%$ and the thermal insulation increased by $8 \%$.

Typically, the use of sludge as raw material in clay brick manufacturing has positive effects on several properties such as: shrinkage, porosity, and strength. Kadir and Rahim [43] analyzed the utilization of diverse types of sludge into fired clay bricks. The results indicated positive effects on the physical and mechanical properties, concluding that the use of sludge should produce better quality bricks.

Therefore, the results of previous studies indicated that bricks produced with sludge showed at least similar quality as regular bricks made from pure clay. Most waste-basedbricks can meet any standard by varying the firing temperature and/or clay-waste mix ratio. If any quality problem occurs, the addition of additives can improve a specific characteristic. Thus, the use of sludge as raw material for brick manufacturing should not represent problems for meeting technical and legal standards. However, it is common for most recycling processes substituting raw source by waste the promotion of a false brick low quality perception on public and industry, leading to product rejection. Hence, there is a need for the brick industry to invest on education and better communication strategies.

Any workable sludge management alternative should consider the initial investment, the distance from generation to processing, and the potential market for the final product. Logistics costs, such as transporting dry sludge over long distances could make the entire process uneconomic. This study assumed that the existing fired clay brick factory within a reasonable distance was a competitive advantage. There is brick manufacturing facility distant 20 kilometers from the lake. Thus, this study indicated the use of sludge as raw material for local brick manufacturing as the most technical, economic, and environmental feasible waste management strategy.

\section{FINAL CONSIDERATIONS}

The objective of this study was to analyze waste management alternatives for disposing the excessive amount of sludge that accumulated over the years in a polluted water resource. Finding viable alternatives for sludge generated on biological lake processes under imperfect information remains a major challenge for public officials and waste managers. 
The alternative preferred by local officials is disposing the sludge is an open-dump area. This illegal option is unrealistic from the environmental standpoint, due to its potential impacts and should not be considered as viable alternative. The sludge disposal on landfill should be assumed as the least preferred alternative, as the major objective is energy and material recovery through recycling or reusing.

The low concentration of contaminants (lead, cadmium, and zinc) made the lake's sludge appropriate for potential use. The sludge should be dewatered before any further action. Before any further action, there should be a prior reduction on the waste (sludge) volume.

In the literature, the typical value of solids found in lakes' sludge is $100 \mathrm{~g} / \mathrm{l}$. In this particular lake, the preliminary results indicated a $271 \mathrm{~g} / \mathrm{l}$ (around three times typical values), which indicates that dehydration should decrease the sludge amount to around $25 \%$ of its original volume.

The results presented in this study have indicated that the sludge characteristics might not vary significantly. The low contamination and organic percentage makes the sludge suitable for brick manufacturing. The use of lake sludge in the local brick manufacturing appears to be most viable alternative. However, there is a severe budget constraint in local municipality that can postpone the implementation of any sludge management strategy.

The other disposal alternatives such as geotextile membrane and incineration could reduce considerably the volume of sludge, as great part of the sludge is composed by water $(75 \%)$. However, these alternatives were considered very costly to a small municipality. Composting is ineffective because of the low organic matter. Agriculture usage entails large logistics costs.

The previous academic studies have indicated that the major restriction for using sludge as raw material is bad information and miscommunication, which leads to public rejection. Once this barrier is defeated, it should be possible to balance technical, economic, and environmental factors to enable marketable brick manufacturing using sludge as raw materials.

As it was described, it would only be possible to truly assess the real technical, environmental, and economic factors of using lake sludge as raw material, after further deeper studies to determine brick characteristics. It will also be necessary to analyze the content of volatile/ fixed solids and the calorific value of different sludge-clay mixture on bricks. These analyses will permit forecasting the behavior of the material during the heating process. However, pathogens should not be a concern, due to high process temperature.

No matter the preferred waste management alternative, the huge amount of sludge generated should be an important variable in the decision-making process, especially considering a small municipality. It is possible, that the most adequate sludge management alternative could be a combination of more than one alternative. The optimal solution should balance environmental, technical, social and economic issues, which means taking a broad-based approach rather than focusing on just a single alternative.

Therefore, the best waste management alternative for treating and disposing the sludge from the selected lake still requires further studies on logistics costs; on mixing ratio, and sludge characteristics (e.g. pathogens and toxic compounds). At this point, the use of lake's sludge in brick manufacturing seemed to be the optimal alternative.

\section{ACKNOWLEDGMENTS}

We thank the Brazilian Research Development Agencies Faperj, Capes and CNPq for the financial support. 


\section{REFERENCES}

[1] Prüss-Ustün, A., Wolf, J., Corvalán, C., Bos, R. \& Neira, M., Preventing Disease Through Healthy Environments, A Global Assessment of the Burden of Disease from Environmental Risks, World Health Organization (WHO), 2016.

[2] National Secretariat of Environmental Sanitation (SNSA). National Information System on Sanitation: Diagnosis of Water and Sewage Services - 2015. Brasilia: Ministry of Cities. 212 p., 2017.

[3] Rebouças, A.C., Waters in the World and in Brazil, in Waters in Brazil: ecological capital, use and conservation, Escrituras Ed, chapter 1, pp. 1-35, 2006.

[4] Braga, B.P.F., Flecha, R., Thomas, P., Cardoso, W. \& Coelho, A.C., Integrated water resources management in a federative country: the case of Brazil. International Journal of Water Resources Development, 25(4), pp. 611-628, 2009. https://doi.org/10.1080/07900620903273432

[5] National Sanitation Federal Law 11.445/2007, available at http://www.planalto.gov.br/

[6] National Environmental Council (CONAMA), Resolution 357/2005, available at http:// www.mma.gov.br/conama

[7] Ministry of Health. Foundation for National Health. Sanitation Manual. 4th Ed. Brasília, 2015.

[8] National Environmental Council (CONAMA). Resolution 430/2011, available at http:// www.mma.gov.br/conama

[9] Ministry of Health. Rule 2.914/2011, available at http://www.saude.gov.br

[10] National Environmental Council (CONAMA). Resolution 274/2000, available at http:// www.mma.gov.br/conama

[11] National Water Agency (ANA). Water Resources in Brasil. Brasilia, 2016.

[12] National Water Agency (ANA). Atlas of Sewage: Depollution of River Basins. National Secretariat of Environmental Sanitation. Brasilia, 2017.

[13] Veiga, M.M., Silva, D.M. \& Veiga, L.B.E., Managing water quality in a polluted lake of Southeast Brazil. International Journal of Sustainable Development and Planning, 8(2), pp. 158-172, 2013.

https://doi.org/10.2495/sdp-v8-n2-158-172

[14] National Environmental Council (CONAMA). Resolution 375/2006, available at http:// www.mma.gov.br/conama

[15] Rio de Janeiro Auditing Authority (TCE), Socioeconomics Study 2005, Miguel Pereira. available at www.tce.rj.gov.br

[16] Veiga, M.M. \& Silva, D.M., Water quality analysis at Javary Lake, Rio de Janeiro. Water Resources Management VI, 145, pp. 297-308, 2011.

https://doi.org/10.2495/wrm110251

[17] Metcalf \& Eddy Inc., Design of Facilities for the Treatment and Disposal of Sludge. Wastewater Engineering, New York, McGraw-Hill, pp. 765-926, 1991.

[18] Volschan Jr, I., Jordão, E.P. \& Paixão, M.C.T., Qualitative Characterization of Sludge Generated by Domestic Sewage Treatment Plants in the Metropolitan Region of Rio de Janeiro. In: $21^{\circ}$ Brazilian Congress on Public Health Engineering, Rio de Janeiro, 2001.

[19] Kenneth Edgell, K., Method Study 37 SW-846 Method 3050. Acid Digestion of Sediments, Sludges and Soils, EPN600/S4-89/012, United States Environmental Protection Agency (USEPA), July 1989.

[20] Abrelpe - Association of Public Cleaning and Special Waste Companies. Overview of Solid Waste in Brazil 2016. São Paulo, 2017. 
[21] Veiga, M.M., Analyzing efficiency of waste reverse logistics for recycling. Waste Management and Research, pp. 1010-1025, 2013.

[22] Santos, A. D., Study of the possibilities of recycling of sewage treatment waste from the Metropolitan Region of São Paulo, 265 p. Dissertation (MSc.), São Paulo Universtiy, São Paulo, 2003.

[23] Denison, R.A., Environmental life-cycle comparisons of recycling, landfilling and incineration: a review of recent studies. Annual Review of Energy and the Environment, 21, pp. 191-237, 1996.

https://doi.org/10.1146/annurev.energy.21.1.191

[24] Morselli, L., Robertis, C., Luzi, J., Passarini, F. \& Vassura, I., Environmental impacts of waste incineration in a regional system (Emilia Romagna, Italy) evaluated from a life cycle perspective. Journal of Hazardous Materials, 159, pp. 505-511, 2008.

https://doi.org/10.1016/j.jhazmat.2008.02.047

[25] Giusti, L., A review of waste management practices and their impact on human health. Waste Management, 29, pp. 2227-2239, 2009. https://doi.org/10.1016/j.wasman.2009.03.028

[26] Kinnaman, T., The economics of municipal solid waste management. Waste Management, 29, pp. 2615-2617, 2009.

https://doi.org/10.1016/j.wasman.2009.06.031

[27] Lara, A.I., Ferreira, A.C., Andreoli, C.V., Pegorini, E.S. \& Ihlenfeld, R.G.K., Use and management of sewage sludge in Agriculture. SANEPAR/PROSAB, Curitiba, 1999.

[28] Andreoli, C.V., Alternatives for Using Sanitation Waste, ABES, Rio de Janeiro, 417 p., 2006.

[29] Cantrell, K.B., Chastain, J.P. \& Moore, K.P., Geotextile filtration performance for lagoon sludges and liquid animal manures dewatering. Transactions of the American Society of Agricultural and Biological Engineers (ASABE), 51(3), pp. 1067-1076, 2008. https://doi.org/10.13031/2013.24526

[30] Raut, S.P., Ralegaonkar, R.V. \& Mandavgane, S.A., Development of sustainable construction material using industrial and agricultural solid waste: a review of waste-create bricks. Construction and Building Materials, 25, pp. 4037-4042, 2011.

https://doi.org/10.1016/j.conbuildmat.2011.04.038

[31] Zhang, L., Production of bricks from waste materials: a review. Construction and Building Materials, 47, pp. 643-655, 2013.

https://doi.org/10.1016/j.conbuildmat.2013.05.043

[32] Kazmi, S.M.S., Abbas, S., Saleem, M.A., Munir, M.J. \& Khitab, A., Manufacturing of sustainable clay bricks: utilization of waste sugarcane bagasse and rice husk ashes. Construction and Building Materials, 120, pp. 29-41, 2016. https://doi.org/10.1016/j.conbuildmat.2016.05.084

[33] Goel, G. \& Kalamdhad, A.S., An investigation on use of paper mill sludge in brick manufacturing. Construction and Building Materials, 148, pp. 334-343, 2017. https://doi.org/10.1016/j.conbuildmat.2017.05.087

[34] Wiemes, L., Pawlowsky, U. \& Mymrin, V., Incorporation of industrial wastes as raw materials in brick's formulation. Journal of Cleaner Production, 142(1), pp. 69-77, 2017. https://doi.org/10.1016/j.jclepro.2016.06.174

[35] Weng, C., Lin, D. \& Chiang, P., Utilization of sludge as brick materials. Advances in Environment Research, 7, pp. 679-685, 2003. https://doi.org/10.1016/s1093-0191(02)00037-0 
[36] Fytili, D. \& Zabaniotou, A., Utilization of sewage sludge in EU application of old and new methods: a review. Renewable and Sustainable Energy Reviews, 12, pp. 116-140, 2008.

https://doi.org/10.1016/j.rser.2006.05.014

[37] Jianfeng, W., Fangwen, L., Xiaohong, X. \& Xianli, S., Preparation of eco-environmental protection bricks from lake Sludge. Journal of Wuhan University of Technology-Mater, Sci. Ed., 23(6), pp. 912-916, 2008. https://doi.org/10.1007/s11595-007-6912-2

[38] Chiang, K.Y., Chou, P.H., Hua, C.R., Chien, K.L. \& Cheeseman, C., Lightweight bricks manufactured from water treatment sludge and rice husks. Journal of Hazardous Materials, 171, pp. 76-82, 2009.

https://doi.org/10.1016/j.jhazmat.2009.05.144

[39] Cusidó, J.A. \& Cremades, L.V., Environmental effects of using clay bricks produced with sewage sludge:Leachability and toxicity studies. Waste Management, 32, pp. 1202-1208, 2012.

https://doi.org/10.1016/j.wasman.2011.12.024

[40] Keffala, C., Harerimana, C. \& Vasel, J.L., A review of the sustainable value and disposal techniques, wastewater stabilisation ponds sludge characteristics and accumulation. Environmental Monitoring and Assessment, 185, pp. 45-58, 2013. https://doi.org/10.1007/s10661-012-2532-1

[41] Tay, J.H., Bricks manufactured from sludge. Journal of Environmental Engineering, 113(2), pp. 278-284, 1987. https://doi.org/10.1061/(asce)0733-9372(1987)113:2(278)

[42] Eliche-Quesada, D., Martínez-García, C., Martínez-Cartas, M.L., Cotes-Palomino, M.T., Pérez-Villarejo, L., Cruz-Pérez, N. \& Corpas-Iglesias, F.A., The use of different forms of waste in the manufacture of ceramic bricks. Applied Clay Science, 52, pp. 270-276, 2011. https://doi.org/10.1016/j.clay.2011.03.003

[43] Kadir, A.B.A. \& Rahim, A.S.B.A., An Overview of Sludge Utilization into Fired Clay Brick. World Academy of Science, Engineering and Technology International Journal of Environmental, Chemical, Ecological, Geological and Geophysical Engineering, 8(8), 2014. 